\title{
CORPORATE SOCIAL RESPONSIBILITY - AN IMPLEMENTATION GUIDE
}

\author{
Cristian Teodorescu ${ }^{1}$, Carol Lehr ${ }^{2}$ \\ 1 GEC - Bucovina, 1 N. Balcescu Str. 720066-Suceava, christit@gmail.com \\ 2 INCD-ECOIND,71-73 Drumul Podul Dambovitei,060652-Bucharest, \\ carolblehr@yahoo.com
}

\begin{abstract}
The paper presents authors' experience in implementing Corporate Social Responsibility (CSR) and aligning it to company sustainable strategy. It starts with a formal commitment expressed by the Company's top management and the nomination of a CSR Team, continues with the elaboration of a CSR Policy, the identification and engagement of stakeholders, the evaluation (by using a multiple criteria decision making matrix) of the most relevant CSR strategic directions that could affect the Company, the structuring of tactical measures (greening technologies, investing in social projects, zero-corruption, work with stakeholders in CSR projects, spread CSR along the value-chain, corporate governance, etc.), action plans, resource allocation, setting up responsibilities, the set up of a CSR plus a synthetic metrics, reporting / monitoring procedures. CSR is integrated in the Company's sustainable strategy (using a specially developed alternative of the Kaplan and Norton's Balanced Scorecard). The paper presents the main steps of the implementing procedure, showing that CSR, environmental, quality and health and safety management systems work together to contribute to a better visibility and business success.
\end{abstract}

Keywords: Corporate Social Responsibility, Stakeholder Engagement, Sustainable Development.

\section{Introduction}

The advent of an international standard dedicated to CSR [1] represents a multi-stakeholder effort to create a basic mainframe for a subject believed as intangible, in many instances. Consequently, the European Commission puts forward in 2011 a new definition of CSR as "the responsibility of enterprises for their impacts on society" and a strategy to put it to work at EU and company's level [2]. This means not only fully compliance to the existing legislation as well as to any collective agreements between business and social partners but also the obligations for companies to elaborate and implement an integrated 
business, social, environmental, ethical, human rights and consumer concerns into their strategy. This should be done in a transparent mode and in close collaboration with all company relevant stakeholders.

The industry is not at its first attempt to open to public scrutiny all its internal processes. The Responsible Care Initiative [3] coming as early as in 1985 from the chemical industry as a result of major catastrophic accidents, set up interesting ways of openness and collaboration among the companies and their stakeholders, including communities, NGOs, media. Romanian initiatives are present $[4,5]$ but rather sparse, hence the motivation for the present paper to detail a guide for CSR implementation at enterprise level.

\section{Implementing CSR}

The main steps and tasks for CSR implementation detailed here are based upon authoritative sources known for their commitment to the triple bottom line sustainable development (economic, environmental, social) [1,6]. They are presented as they have been used in specific cases for Romanian companies, together with barriers encountered and how they have been overcome.

Task 0: Commitment of the Company's top management is essential. It is expressed in a formal document, explicitly nominating a CSR Team and its Responsible. The employees must realize that the commitment is genuine and that implementing CSR will not end with a document to be shelved and forgotten. Here the role of an external advisor proved essential in order to smoothen the collaboration among all team members and resolve potential conflicts. For all the CSR Team members it was important to understand that they are working together as equal partners, each coming with his own expertise and background, forgetting hierarchical differences. Ideas and opinions must be encouraged to flow free. Critical analysis will come later.

Task 1: Initial CSR audit and assessment. A presentation of what CSR is and what should be the outcomes of the implementing process is made by the external advisor. Questionnaires and interviews are then conducted by the external advisor would lead to assess where exactly the company is in the field of CSR (not where the top managers believe it is!). In order to access all relevant and sensitive aspects in the Company, questionnaires were forwarded to the external advisor unsigned and interviews were conducted separately with all managers and other stakeholders in the Company (e.g., head of employees' union) as well with selected stakeholders. The conclusions of this task are presented to the CSR Team. Differences between the existing situation and the expected final result of the CSR implementation are underlined.

A list of issues, classified along their relevance for the company and along the capacity of the company to sort them out is set up at this stage, The CSR Team starts now working on a CSR Policy of the Company, a short, synthetic, mobilizing document endorsed by all employees. The process should not be hurried as the CSR Team is learning only little by little what CSR is. A final version of the Policy would come at the very end of the implementation process, after a trial \& error process and confrontation with new CSR aspects, with Board members wishes, etc. 
Task 2: Identifying and engaging stakeholders. A list of potential stakeholders and their place and inter-relations is presented in Fig. 1 [7].

As can be seen from the illustration, inner categories of stakeholders are present in outer categories as well, meaning, e.g., those employees may occasionally become customers or are currently members of the communities, while still maintaining their connections and interests in the Company business. On the other hand, though members of the communities or Administrative Authorities, also potential customers of the company, have no economic interest or relationship with the company and are no formal part whatsoever in that company.

The framework in Fig. 1 must be regarded in the broader framework of current trend of globalization where accelerated technology development creates new contexts in which CSR become more and more important. It means that individual companies have responsibilities not only against their customers or employees but must pro-actively think to what effects their business could affect environmental and social issues at global level. At this point, the CSR Team must realize the real challenges put to the Company and why openness and cooperation with all stakeholders is in their interrest and essential for the future. Stakeholder engagement must be done as early as possible in the process of CSR Implementation, but not before all the CSR Team members has established their consensual shared point of view about what CSR is what are its expectations. A workshop gathering all identified stakeholders should be organized as early as possible, but only when the CSR Team could answer all potential questions and could pertinently comment upon all remarks coming from the participants.

\section{Societal Stakeholders:}

Governmental, Administration and other relevant Authorities (e.g., regulators, enforcing entities)

Environment and environmental authorities

NGOs

Communities and individuals

International Organizations (Human Rights, Environment, etc.)

Media

\section{Business Stakeholders:}

Members of the value chain (suppliers, distributors, customers)

Financing authorities (banks, creditors, EU agencies)

Industry Associations (e.g., in the field of chemistry, pulp and paper, cement, etc.)

\begin{tabular}{|l|}
\hline Organizational \\
Stakeholders: \\
Employees \\
Unions \\
Management \\
Stockholders \\
\hline
\end{tabular}

Figure 1. Categories of Company's stakeholders. 
At the Company initiative, a Project Advisory Board (PAB) should be organized at this stage, grouping representatives of the most important stakeholders, renowned experts, respected members of the communities, etc. Their role is:

a. To guide the CSR Team by evaluating and censoring its actions, legitimate them so that they are tailored exactly upon what the company $\&$ its stakeholders, as a whole body, believe is best for everyone.

b. To enable straightforward interaction with all stakeholders, with the general public and media

c. To add their expertize to Company's experts, by covering fields up to now not considered in the decision making process of the Company (environmental, cultural, historical, particular social aspects).

Engaging stakeholders triggers new processes that the Company must learn how to manage and could, in principle, span over a continuum of interaction that reflects the degree of influence stakeholders are allowed to have in decision making. At one end, businesses might simply inform stakeholders of their plans. At the other, stakeholders can be deeply involved in the decision making process [6]. The relationship among Company and stakeholders will change in time. As a first step, both parts must make efforts to accept and understand each other as partners and establish a mode of communication.

Task 3: Develop CSR commitments. There are only a few identified strategic directions of actions or programs for substantiating a CSR process. They are briefly presented in the subsequent paragraphs. See [4] for a detailed discussion:

a. Cause promotion. The Company frees resources in order to increase its visibility in supporting a cause, to increase public awareness to mobilize the public to donate or participate to the cause

b. Cause Related Marketing. For a limited period of time, the Company donates in favour and benefit of an entity (e.g., $2 \%$ of sales of a specific product go to the provide equipment for specific hospitals)

c. Corporate Social Marketing. The Company fights against a negative aspect or a dramatic situation (family violence, helping people with disabilities, fight against pesticides in food, etc.). It contributes to the change of the public behaviour as a consequence of this focused action of the Company.

d. Corporate Philantropy. The Company directly contribute to support an urgent case (saving a community affected by a catastrophe, help some individuals to go abroad for learning, medical treatment, taking part into contests, etc.).

e. Community Volunteering. The Company encourages its employees to take part in supporting a community or a cause (employees and equipment, wearing Company's logo go cleaning a National Reservation, go building houses for poorer families, etc.).

The 5 CSR main directions presented above may be complemented, in a specific case, by additional strategic action interesting a Company. Not all these directions are of the same importance and come with the same benefits for the company in the short, medium or long term. In addition, Company's resources for such programs are very limited so they must be spent to get the most benefit 
of it. A Multi-Criteria-Decision-Making Matrix is used to classify the Company's actions along the 5 strategic directions mentioned above. Stakeholders and Company representatives are requested to fill in a template like in Table 1 in order to establish the priority of actions. The Table illustrates a simple situation where only the 5 lines of actions and only 4 stakeholders are considered. Each stakeholder is asked to give scores from 1 (less relevant in the context and at the moment of decision) to 5 (most relevant in the same context). Each row must contain a " 1 " and a " 5 ". The final scores are obtained by adding up individual scores. In the present case, the "Social Marketing" gets the highest score, so the company must start working on this issue, not forgetting the other 2 lines of action having top scores of " 12 ".

Table 1. Form to be completed for CSR decision making.

\begin{tabular}{|l|c|c|c|c|c|}
\hline & $\begin{array}{c}\text { Cause } \\
\text { Promotion }\end{array}$ & $\begin{array}{c}\text { Cause } \\
\text { Marketing }\end{array}$ & $\begin{array}{c}\text { Social } \\
\text { Marketing }\end{array}$ & Philantropy & Volunteering \\
\hline Managers & 2 & 1 & 5 & 3 & 3 \\
\hline Employees & 1 & 5 & 4 & 2 & 1 \\
\hline Customers & 1 & 4 & 3 & 5 & 2 \\
\hline Community & 4 & 2 & 1 & 4 & 5 \\
\hline SCORE & $\mathbf{8}$ & $\mathbf{1 2}$ & $\mathbf{1 3}$ & $\mathbf{1 2}$ & $\mathbf{1 1}$ \\
\hline
\end{tabular}

Such decision-making processes should become common for the Company's managers. A very important intangible by-result is that, in the process, stakeholders learn to work together, cooperate, exchange views, and understand each other. The approach can become more complex by allocating a relevance index to each stakeholder (e.g., distributors or suppliers cannot be as important as communities or Environment). And instead of simply adding up scores attributed by all stakeholders, a more elaborated Spearman rank correlation coefficient procedure could lead to the final consolidated scores. The CSR Team will feel, in time, the need for a more sophisticated approach and it must be encouraged to identify and apply such approaches.

Such a procedure, however, cannot be used when the Company must take a decision on the spot (e.g., support an individual in a very bad need of help). It is important to note that the above procedure must be doubled by a very strong ethical component and a wish to do-good, before pondering what could be the outcome for the business. It is the managers' choice to advertise their actions as loudly and cynically as possibly or let the actions speak for themselves. An educated public would be more sensitive to the later approach.

Task 4: Put CSR in practice. Each line of action mentioned above can be implemented at tactical level, using many more detailed activities.

Examples:

- Corporate Governance

- Cleaner Production, ZERO-Waste and Industrial Symbiosis

- Environmentally friendly products

- Educating communities

- Involving schools

- No bribery, zero corruption 
- Value chain observing the triple bottom line of sustainability

- Creating action programs together with communities

- Rewards for individuals showing most interest in CSR

- Reporting along recognized frameworks (e.g., GRI [8], Financial Times FTSE4Good [9], Dow Jones DJSI [10]), etc.

Such activities should be included in Action Plans for implementing each specific CSR issue.

Putting Action Plans in practice will follow a procedure similar to the well known Deming Cycle (Plan - Do - Check - Act) in the way that a detailed plan will be followed by resource allocation and practical actions, by a feedback connection to monitor progress and results and by a procedure to correct and improve the implementation process. It is important to underline that the Action Plans should involve all relevant stakeholders. This is done by creating task teams or working groups.

The monitoring and reporting tasks are also the attributes of all stakeholders involved (communication, dialogue are therefore essential). Sharing responsibility will alleviate the burden of the Company and could add resources to the process, creating in the same time a cooperative environment for future CSR programs. As a Company's resources are limited, CSR actions could engage more than one Company, joining resources and sharing benefits. An important aspect related to Action Plans is the Key Performance Indicators set that must be associated to them. A detailed procedure to establish the set of KPI may be found in $[6,7,11]$.

Task 5: CSR and the Company strategy. CSR alignment to the existing strategy should be done along the triple bottom line of sustainable development.

Starting from the well-known Kaplan and Norton's Balanced Scorecard system of strategic management [11], the CSR Team should identify CSR objectives and insert them in the Company's strategy. A way to do it is presented in Fig. 2. The Strategic Map of the Company, organized along the classical 4 perspectives of the Balanced Scorecard is divided along the three pillars of sustainability (economic, environment, social).

Organizing the strategic objectives in a Map like that in Fig. 2, have the following advantages:

- The strategic map is a public document in which stakeholders will recognize their initiatives and the commitment of the Company's managers to put them into practice;

- It is a powerful communication vector for the public. It shows that the Company is equally concerned by all aspects of sustainable development

- During the implementation phase, once a strategic objective is not fulfilled, such a strategic map could show what the consequences are. Those responsible for not doing their job as expected will support all the consequences.

- Starting from this map, each objective is detailed (Action Plans, resources, Key Performance Indicators and associated targets, monitoring and reporting procedures, etc.). We also used a synthetic metrics of the process at this stage - much appreciated by managers who could monitor at a glance how the Company progresses. A 
procedure to compute a composite index for sustainability starting from particular $\mathrm{KPI}$ is presented in [12]. For the procedure to obtain an ecoefficiency index as the ratio between a business indicator (e.g., production value) and the associated environmental impact index (e.g., environmental expenditures), see $[13,14]$

\begin{tabular}{|c|c|c|c|c|}
\hline & & \multicolumn{3}{|c|}{ Destination Statement (comes from company's Mission/Vision) } \\
\hline \multirow{5}{*}{ 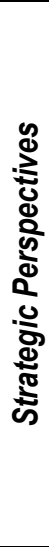 } & $\begin{array}{l}\text { Financial } \\
\text { Perspective } \\
\end{array}$ & Increase Shareholders value & Green Company & $\begin{array}{c}\text { Profit from CSR } \\
\text { (FTSE4Good;DJSI) } \\
\end{array}$ \\
\hline & Stakeholders & $\begin{array}{l}\text { Cooperation along the value } \\
\text { chain }\end{array}$ & $\begin{array}{l}\text { Green } \\
\text { Procurement }\end{array}$ & $\begin{array}{l}\text { Engaging Stakeholders } \\
\text { In the decision making }\end{array}$ \\
\hline & $\begin{array}{l}\text { Internal } \\
\text { Processes }\end{array}$ & BAT-BREF, Quality - ISO9001 & EMS - IS014001 & Employees' satisfaction \\
\hline & & & & \\
\hline & Learning\&Growth & $\begin{array}{c}\text { Continual Learning } \\
\text { Valuing Employees' innovative } \\
\text { ideas } \\
\end{array}$ & $\begin{array}{c}\text { Environmental } \\
\text { Reconstruction, } \\
\text { etc. }\end{array}$ & $\begin{array}{l}\text { Involvement in social } \\
\text { projects }\end{array}$ \\
\hline & & Economic & Environment & Social \\
\hline & & 3 pilla & Istainable Develc & \\
\hline
\end{tabular}

Figure 2. Company's Strategic Map including CSR Objectives.

CSR elements are present not only in the "SOCIAL" pillar of the map but also in other parts (Green Company, Valuing employees' innovative ideas, etc.). It shows the strong correlation among all the three elements of sustainable development and their concerted action for the final result (Increasing shareholders value) now standing on better foundations.

\section{Conclusions}

At the end of the implementation process, conducted by the CSR Team, the Company has got the following:

- A specialized team of experts, now familiar with CSR issues and challenges.

- A list of stakeholders (to be updated whenever need be) that became a part of the decision making process of the Company and specific procedures to communicate, cooperate and work together with them. They are also involved in the CSR objective selection and classification.

- Detailed Action Plans for implementing CSR issues. Putting them into practice is the task of all relevant stakeholders.

- A Project Advisory Board that could be involved in future actions, as it already knows best the Company and its environment.

- A CSR Policy Document endorsed by all employees and in accordance with stakeholders' expectations 
- An updated strategy, including CSR objectives aligned to all other main objectives of the company, in the framework of the triple bottom line of sustainable development.

- A coherent set of KPI and a synthetic metrics enabling managers to assess Company's performance in CSR and sustainability

- As a result of implementing CSR, the Company could decide to report using internationally recognized frameworks $[8,9,10]$, becoming familiar with the global business environment and its challenges. Usually this is very motivating for managers who will strive to go up on the sustainability indexes established by these reporting procedures.

As for the outcomes of the CSR actions:

- Romanian Companies are only starting thinking and implementing CSR

- The general public is not yet sensible to CSR actions as it should be; e.g., the "Tara lui Andrei" ("Andrei's Country") campaign sustained by a Romanian Oil \& Gas Company was very successful when it came to donations and financing Projects. But CSR is a philosophical paradigm and a way of life and action, much more that money. A national, raising awareness campaign is needed to educate the public but it will take time before seeing sensible results.

- When a single Company is implementing CSR in a geographical area, stakeholders (especially communities, individuals, NGOs) will try to get the most out of Company resources. In time they will realize that they will be stakeholders for many other companies in the area so that they will get benefits from many sources

- Romanian Companies observing the CSR priorities are, on the other hand, much appreciated by EU / international agencies when it comes to funding local projects so the effort needed to implement CSR is paying off, generously.

CSR is not specific to larger companies. Every business entity should understand and implement the CSR concept with increased awareness for the impact they generate upon the society and the environment, now and in the future.

CSR adds a new dimension to the business activity of a given company. Managers must learn fast how to cooperate with their neighbours, with communities, they should recognize, accept and see the involvement of all stakeholders in the decision making process as an opportunity..

Quality, environmental and health \& safety management systems should not be independent but rather work together to sustain the business of the Company. Now CSR expand the horizon beyond the Company fences, including in its dayby-day activity a long list of all those that may regulate, may be interested or affected by what the Company does.

The procedure illustrated here has been applied to Romanian SMEs. A Project financed by Innovation Norway, active and operational at a ceramic tile manufacturer in Cluj and enjoying the expertise of Norwegian specialists has a component dedicated to the implementation of the CSR in a large Romanian enterprise. 


\section{References}

[1] ISO26000 (2010), Guidance on Social Responsibility, ISO copyright office, CP56, CH-1211, Geneva, Switzerland

[2] EU-CSR Strategy (2011), COM(2011)-681: A renewed EU strategy 2011-14 for Corporate Social Responsibility, European Commission, http://eurlex.europa.eu/legal-content/EN/TXT/PDF/?uri=CELEX:52011DC0681\&from=EN , retrieved, August 2, 2015

[3] Responsible Care (2015) http://www.icca-chem.org/en/Home/Responsible-care/, accessed August 2, 2015

[4] CSR-Romania (2015), Studiu privind implicarea companiilor din Romania in activitati de "Responsabilitate Sociala Corporatista, http://centras.tree.ro/assets/upload/File/Raport\%20RSC.doc

[5] CSR-Romania (2011), Responsibilitate Socială (Corporativă) în România, http://undp.ro/libraries/projects/CSR/deliverables/Analiza\%20Situatiei\%20RSC\% 20in\%20Romania\%20RO(1).pdf , retrieved July 18, 2015

[6] Hohnen, P. (2007), Corporate Social Responsibility: An Implementation Guide for Business, International Institute for Sustainable Development, Winnipeg, Canada

[7] Werther, W.B.Jr. and Chandler, D. (2006), Strategic Corporate Social Responsibility, Sage Publications, Thousand Oaks, California, United States

[8] GRI (2015), Global Reporting Initiative, https://www.globalreporting.org/Pages/default.aspx , accessed August 5, 2015

[9] FTSE4Good (2015), The FTSE4Good Index Series measuring the Environmental, Social and Governance performance of companies, http://www.ftse.com/products/indices/FTSE4Good accessed August 5, 2015

[10] DJSI (2015), The Dow Jones Sustainability Index, http://www.sustainabilityindices.com/ accessed August 5, 2015

[11] The Balanced Scorecard Institute (2015), http://balancedscorecard.org/ , accessed August 5, 2015

[12] Teodorescu, C. and Danubianu, Mirela (2015), Industrial Symbiosis, Ecoefficiency, Sustainability - A Case Study, Present Environment and Sustainable Development Journal, 9(1), pp. 169-180, "Al.I.Cuza" University lasi, Romania

[13] Teodorescu, C. et al. (2011), Applying Life Cycle Analysis Of Industrial Products To Macroeconomic Level, Paper \#II-O-20 presented at the International Symposium "The Environment and the Industry", SIMI-2011, organized by ECOIND - Bucharest.

[14] NSK CSR (2015), Social and Environmental Activities, http://www.kr.nsk.com/investors/pdf/documents/ar201003e 13.pdf , retrieved Aug $5,2015$. 